\title{
Recurrence risk figures for isolated tetralogy of Fallot after screening for 22q11 microdeletion
}

\author{
M C Digilio, B Marino, A Giannotti, A Toscano, B Dallapiccola
}

\begin{abstract}
Isolated tetralogy of Fallot (TF) has a multifactorial mode of inheritance in most cases, and recurrence risk rates of $2.5-3 \%$ have been attributed to first degree relatives of an affected child. In a subgroup of patients with a strong family history, the transmission of a monogenic trait has been suspected. Microdeletion $22 q 11$ (del(22q11)) can cause $T F$ in the setting of DiGeorge and velocardiofacial syndromes, and has also been related to familial conotruncal cardiac defects. Empirical risk figures in families after exclusion of del(22q11) have never been calculated. We have investigated the overall occurrence of congenital heart defect (CHD) in relatives of 102 patients with isolated non-syndromic TF previously screened for del(22q11). Our results show that the frequency of CHD is $3 \%$ in sibs, $0.5 \%$ in parents, $0.3 \%$ in grandparents, $0.2 \%$ in uncles or aunts, and $0.6 \%$ in first cousins. The recurrence risk rate for sibs in our series is the same as that previously estimated, indicating that after exclusion of patients with del(22q11) genetic counselling to patients with isolated TF should not be modified. A high concordance rate among our affected sibs has been documented. Gene(s) different from those located on chromosome $22 q 11$ must be involved in causing familial aggregation of non-syndromic TF in these cases. (f Med Genet 1997;34:188-190)
\end{abstract}

Departments of Medical Genetics and Pediatric Cardiology, Bambino Gesù Hospital, Piazza S Onofrio 4, 00165 Rome, Italy M C Digilio B Marino A Giannotti A Toscano

Department of Public Health and Cell Biology, University of Tor Vergata, Rome, and CSS Hospital, San Giovanni Rotondo, Italy

B Dallapiccola

Correspondence to: Dr Marino.

Received 24 July 1996 Revised version accepted for publication 17 October 1996
Keywords: congenital heart defect; tetralogy of Fallot; recurrence risk; genetic counselling.

Tetralogy of Fallot (TF) is the most common cyanotic congenital heart defect (CHD), affecting 2.5 to 3.5 per 10000 live births, ${ }^{1}$ and representing $4 \%$ to $7.5 \%$ of all forms of cardiac malformation. ${ }^{2}$ The recurrence risk for $\mathrm{CHD}$ in sibs of patients with isolated TF has been estimated as 2.5 to $3 \%{ }^{3}$ There is evidence for multifactorial determination, ${ }^{34}$ although single gene inheritance has been suspected in a subgroup of cases with a strong family history. ${ }^{5-10}$

TF is associated with extracardiac anomalies in $30 \%$ of cases. ${ }^{11}$ In particular, TF occurs in branchial arch syndromes owing to $22 \mathrm{q} 11$ microdeletion (del(22q11)), including $\mathrm{Di}$ George, velocardiofacial, and conotruncal anomaly face syndromes. ${ }^{12-14} \operatorname{Del}(22 \mathrm{q} 11)$ has been detected in familial conotruncal CHDs, ${ }^{15} 16$ although our experience ${ }^{17}$ and molecular studies performed by others ${ }^{18}$ have shown little influence of del(22q11) in causing sporadic or familial non-syndromic TF. It is therefore not known if recent molecular discoveries regarding the $22 \mathrm{q} 11$ chromosomal region should modify the information about recurrence risks in genetic counselling of families with an affected child.

We investigated the overall occurrence of $\mathrm{CHD}$ and the recurrence risk in relatives of patients with isolated non-syndromic TF previously screened for del(22q11).

\section{Patients and methods}

From January 1993 to March 1996, 150 consecutive patients with $\mathrm{TF}$ were evaluated at the Department of Paediatric Cardiology in our hospital. A diagnosis of CHD was reached with echocardiography and confirmed with cardiac catheterisation, surgery, or necropsy in all probands. Patients with associated pulmonary atresia ${ }^{19}$ were excluded from the study. All patients underwent clinical and phenotypic evaluation in order to identify major and minor extracardiac anomalies. Standard karyotyping on peripheral lymphocytes was performed, and fluorescent in situ hybridisation (FISH) was used for detecting del(22q11) in all cases. ${ }^{17}$

Clinical evaluation showed that 48 of the 150 patients were syndromic. ${ }^{20}$ Velocardiofacial and DiGeorge syndromes were diagnosed in 17 cases, Down syndrome in 20, and other genetic conditions in 11 . The remaining 102 patients had non-syndromic TF. Chromosomal analysis showed trisomy 21 in all patients with Down syndrome, and was normal in the other cases. $\operatorname{Del}(22 \mathrm{q} 11)$ was detected by FISH in nine syndromic patients with a clinical diagnosis of velocardiofacial or DiGeorge syndromes.

Of the 102 patients with isolated TF by normal standard chromosome and FISH analysis, five were excluded because they were adopted and the family history was not evaluable. The 97 patients included in the study were investigated in detail for familial occurrence of cardiac malformations. There were 62 male and 35 female patients. Their mean (SD) age was 6.52 (3.74) years (age range, newborn to 16.2 years). Family pedigrees were constructed to include first and second degree relatives and first cousins. There were 290 first degree relatives (194 parents, 96 sibs, and no children), 960 second degree relatives (388 grandparents, 572 uncles or aunts, and no nephews), and 938 first cousins. Documentation of all identified cases of CHD in family members was obtained using methods similar to those used in the proband group. All living first degree relatives 
Table 1 Empirical risk figures obtained in the present series of patients with tetralogy of Fallo

\begin{tabular}{lll}
\hline Relationship & $\begin{array}{l}\text { No of affected family members/ } \\
\text { total no of family members }\end{array}$ & Risk (\%) \\
\hline First degree & $4 / 290$ & 1.4 \\
Parents & $1 / 194$ & 0.5 \\
Sibs & $3 / 96$ & 3.1 \\
Second degree & $2 / 960$ & 0.2 \\
Grandparents & $1 / 388$ & 0.3 \\
Uncles/aunts & $1 / 572$ & 0.2 \\
First cousins & $6 / 936$ & 0.6 \\
\hline
\end{tabular}

Table 2 Discordant cardiac defects in relatives of patients with isolated tetralogy of Fallot

\begin{tabular}{ll}
\hline Defect & Relationship \\
\hline Pulmonary stenosis (valvular) & Mother \\
& First cousin \\
Atrial septal defect & Grandmother \\
Aortic coarctation & First cousin
\end{tabular}

underwent clinical and electrocardiographic examination. In families in which $\mathrm{CHD}$ occurred in more than one member, a complete echocardiographic study was performed on all first degree relatives and on the living second degree relatives. When $\mathrm{TF}$
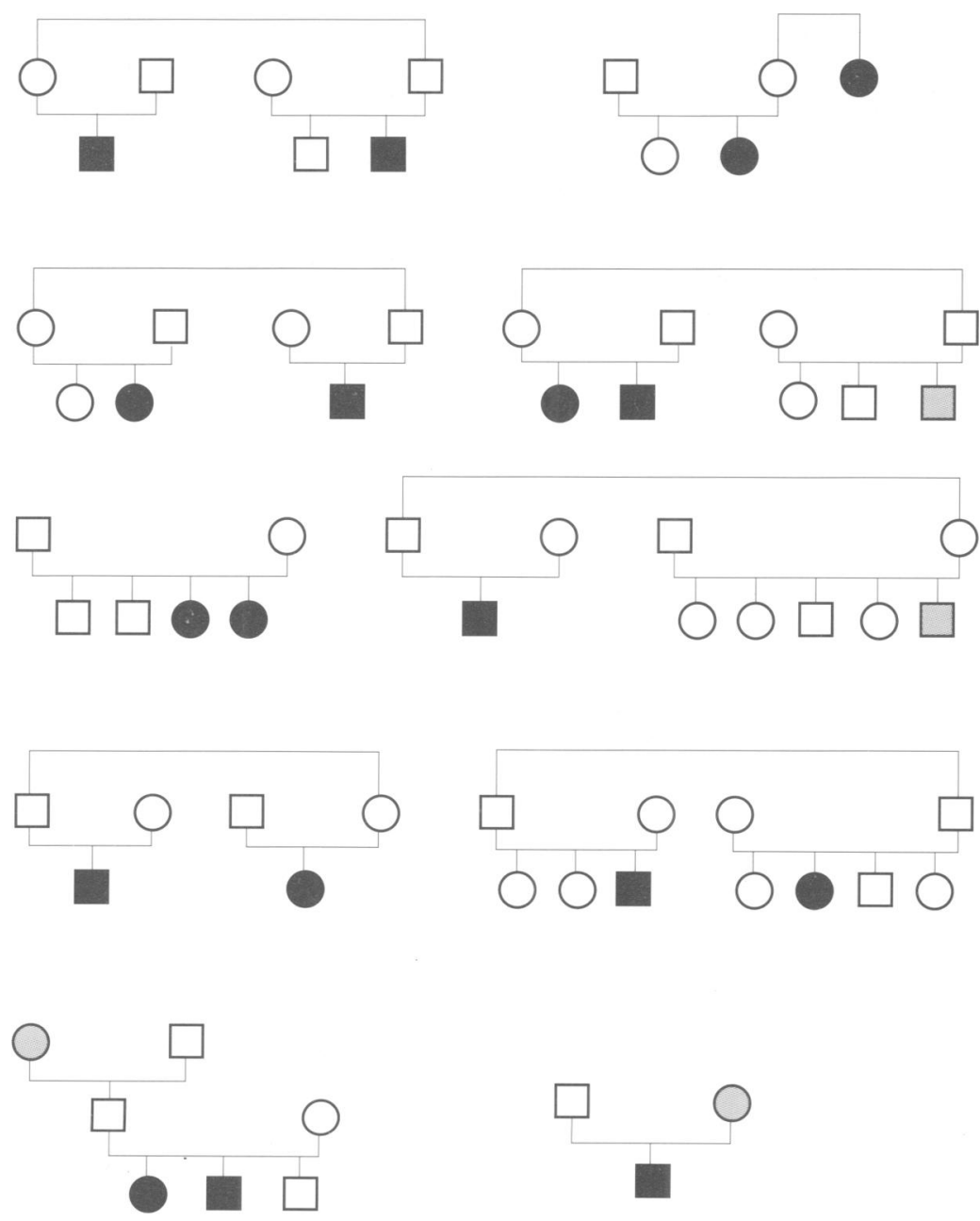

: Tetralogy of Fallot

Discordant congenital heart defect

Figure 1 Pedigree of 10 families of probands with tetralogy of Fallot and additional family member affected by congenital heart defect. occurred in more than one family member, only one proband was considered to be the index case.

\section{Results}

Ten $(10.3 \%)$ of the 97 patients with TF had at least one relative with $\mathrm{CHD}$. The pedigrees are shown in fig 1 . The occurrence of CHD and the recurrence risk rates for first and second degree relatives and first cousins are detailed in table 1. CHD in affected sibs was concordant in all cases (fig 1). In addition, $\mathrm{TF}$ was diagnosed in one aunt. The concordance rate in first cousins was $67 \%(4 / 6)$. The types of discordant CHD in affected relatives are shown in table 2. Three sets of parents with single, affected children were related (first cousins in two cases, second cousins in one).

\section{Discussion}

Recurrence risk rates of 2.5 to $3 \%$ are attributed to first degree relatives of an affected child with non-syndromic TF. $^{3}{ }^{21-23}$ However, empirical risk figures in families of patients previously screened for $\operatorname{del}(22 \mathrm{q} 11)$ have never been calculated. Our results show that, after exclusion of patients with branchial arch syndromes owing to del(22q11), genetic counselling to families with isolated TF should not at present be modified. The frequency of CHD in sibs in the present series $(3.1 \%)$ is, in fact, similar to that previously estimated. ${ }^{3}$ Interestingly, in each of the three families with vertical transmission of CHD the affected relative is female, in agreement with previous reports suggesting that the recurrence risk for CHD is substantially higher if the affected parent is the mother rather than the father. ${ }^{24}$ It is furthermore noticeable that in our series the incidence of CHD in cousins is inexplicably higher than that in second degree relatives.

Familial aggregation of TF has been documented in previous reports. ${ }^{5-10}$ The high concordance rate in affected sibs has also been noted in our series. Monogenic inheritance of TF in families with more than one affected member has been suspected. Autosomal recessive transmission has been hypothesised, following the observation of recurrence of TF in two or three sibs. ${ }^{5-10}$ The occurrence of conotruncal CHD in keeshond dogs after inbreeding studies have suggested the involvement of a single major gene, probably interfering with myocardial growth during embryonic development. ${ }^{25} \mathrm{~A}$ population based study has shown a reduction in risk for conotruncal heart defects in offspring of women who used a multivitamin containing folic acid periconceptionally, ${ }^{26}$ suggesting a causal association between multivitamin deficiency and specific cardiac malformations. $\operatorname{Del}(22 q 11)$ has been previously detected in families with parent to son/daughter transmission of conotruncal CHD. ${ }^{15}{ }^{16}$ Subtle anomalies in the setting of velocardiofacial syndrome have been noted in these cases ${ }^{18}$ which should not be considered as truly "isolated". The absence of a detectable del(22q11) in our patients supports the hypothesis that non-syndromic TF, including familial and sporadic cases, is not the 
result of this chromosomal imbalance. ${ }^{17}$ Interestingly, del(22q11) has never been found in families with recurrence of TF in sibs born to normal parents. ${ }^{18}$ Moreover, in patients with $\mathrm{TF}$ and branchial arch syndromes resulting from del(22q11) distinct additional cardiovascular defects are prevalent. ${ }^{20}{ }^{23}$ Our results further suggest that gene(s) different from those located on chromosome $22 \mathrm{q} 11$ are implicated in the pathogenesis of familial non-syndromic TF.

1 Ferencz C, Rubin RD, McCarter RJ, et al. Congenital heart disease: prevalence at livebirth. The Baltimore-Washington Infant Study. Am f Epidemiol 1985;121:31-6.

2 Boughman JA, Berg KA, Astemborski JA, et al. Familia risks of congenital heart defect assessed in a populationbased epidemiologic study. Am ₹ Med Genet 1987;26:83949 .

3 Nora JJ, Nora AH. The evolution of specific genetic and environmental counseling in congenital heart disease. Circulation 1978;57:205-13

4 Nora JJ. Multifactorial inheritance hypothesis for the etiology of congenital heart diseases. The genetic environmental interaction. Circulation 1968;38:604-17.

5 Miller ME, Smith DW. Conotruncal malformation complex: examples of possible monogenic inheritance. Pediatrics 1979;63:890-3.

6 Der Kaloustian VM, Ratl H, Malouf J, et al. Tetralogy of Fallot with pulmonary atresia in siblings. $\mathrm{Am} \mathcal{F} \mathrm{Med}$ Genet 1985;21:119-21.

7 Pankau R, Siekmeyer W, Stoffregen R. Tetralogy of Fallot in three sibs. Am F Med Genet 1990;37:532-3.

8 Cassidy SC, Allen HD. Tetralogy of Fallot in triplet siblings. Am ₹ Cardiol 1991;67:1442-4.

9 Wulfsberg EA, Zintz EJ, Moore JW. The inheritance of conotruncal malformations: a review and report of two sibconotruncal malformations: a review and report of two sibGenet 1991;40:12-16.

10 Pacileo G, Musewe NN, Calabrò R. Tetralogy of Fallot in three siblings: a familial study and review of the literature. Eur F Pediatr 1992;151:726-7.

11 Ferencz C, Rubin JD, McCarter RJ, et al. Cardiac and noncardiac malformations: observations in a population-based study. Teratology 1987;35:367-78.

12 Marmon LM, Balsara RK, Chen R, Dunn JM. Congenita cardiac anomalies associated with the DiGeorge syndrome: a neonatal experience. Ann Thorac Surg 1984;38:146-50.
13 Young D, Shprintzen RJ, Goldberg RB. Cardiac malformations in the velocardiofacial syndrome. Am $\mathcal{F}$ Cardiol 1980; 46:643-8.

14 Van Mierop LHS, Kutsche LM. Cardiovascular anomalies in DiGeorge syndrome and importance of neural crest as a possible pathogenetic factor. Am 7 Cardiol 1986;58:133-7.

15 Wilson DI, Goodship JA, Burn J, Cross IE, Scambler PJ. Deletions within chromosome $22 \mathrm{q} 11$ in familial congenital heart disease. Lancet 1992;340:573-5.

16 Goldmuntz E, Driscoll D, Budarf ML, et al. Microdeletions of chromosomal region 22q11 in patients with congenital conotruncal cardiac defects. F Med Genet 1993;30:807-12.

17 Amati F, Mari A, Digilio MC, et al. 22q11 deletions in isolated and syndromic patients with tetralogy of Fallot. Hum lated and syndromic patie
Genet 1995;95:479-82

18 Debrus S, Berger G, de Meeus A, et al. Familial non-syndromic conotruncal defects are not associated with a 22q11 microdeletion. Hum Genet 1996;97:138-44.

19 Digilio MC, Marino B, Grazioli S, Agostino D, Giannotti A, Dallapiccola B. Comparison of occurrence of genetic syndromes in ventricular septal defect with pulmonic stenosis (classic tetralogy of Fallot) versus ventricular septal defect with pulmonic atresia. Am f Cardiol 1996;77: tal defe

20 Marino B, Digilio MC, Grazioli S, et al. Associated cardiac anomalies in isolated and syndromic patients with tetralogy of Fallot. Am $\mathcal{F}$ Cardiol 1996;77:505-8.

21 Boon AR, Farmer MB, Roberts DF. A family study of Fallot's tetralogy. 7 Med Genet 1972;9:179-88.

22 Sanchez-Cascos A. The recurrence risk in congenital heart disease. Eur $\mathcal{F}$ Cardiol 1978;7:197-210.

23 Boughman JA, Neill CA, Ferencz C, Loffredo CA. The genetics of congenital heart disease. In: Ferencz C, Rubin $\mathrm{JD}$, Loffredo CA, Magee CA, eds. Epidemiology of congenital heart disease - The Baltimore-Washington Infant Study 19811989. Mount Kisco, NY: Futura Publishing Company, 1993.

24 Nora JJ, Nora AH. Maternal transmission of congenital heart diseases: new recurrence risk figures and the questions of cytoplasmic inheritance and vulnerability to teratogens. Am F Cardiol 1987;59:459-63.

25 Patterson DF, Pexieder T, Schnarr WR, Navratil T, Alaili R A single major-gene defect underlying cardiac conotruncal malformations interferes with myocardial growth durin embryonic development: studies in the CTD line of keeshond dogs. Am ₹ Hum Genet 1993;52:388-97.

26 Shaw GM, O'Malley CD, Wasserman CR, Tolarova MM, Lammer EJ. Maternal periconceptional use of multivitamins and reduced risk for conotruncal heart defects and limb deficiencies among offspring. Am $7 \mathrm{Med}$ Genet 1995;59:536-45. 